\title{
PENINGKATAN PENGETAHUAN DAN KETAMPILAN PENGOLAHAN PRODUK PETERNAKAN DI DESA CIBEREUM KECAMATAN TALAGA
}

\author{
Kusmajadi Suradi, Andry Pratama, dan Wendry S. Putranto \\ Lab. Teknologi Pengolahan Produk Peternakan, Departemen THP, Fakultas Peternakan Universitas Padjadjaran \\ E-mail: andry.pratama@unpad.ac.id
}

\begin{abstract}
ABSTRAK. Pemenuhan bahan pangan berkualitas dengan jumlah yang mencukupi merupakan salah satu upaya yang harus ditempuh untuk tercapainya kesejahteraan masyarakat dalam era globalisasi saat ini. Sayangnya di Desa hal ini belumlah terpenuhi secara merata. Keterbatasan pangetahuan dan keterampilan menjadi salah satu penyebabnya. Pengenalan dan penganekaragaman produk berbahan dasar hasil ternak merupakan salah satu solusi yang tepat. Potensi ternak dan sumber daya manusia (kelompok PKK) yang ada desa Cibereum diharapkan dapat menunjang pendapatan dan kebutuhan masyarakat akan tersedianya makanan bergizi, khususnya protein hewani. Metode yang digunakan pada kegiatan ini adalah penyuluhan dan pendekatan baik secara personal maupun kepada kelompok PKK yang ada di Desa Cibereum. Hasil dari program pengabdian kepada masyarakat dapat meningkatkan pengetahuan kelompok PKK mengenai teknologi pengolahan dan penganekaragaman produk yang baik. Hasil uji T-test tingkat pengetahuan peserta sebelum dan sesudah penyuluhan menunjukan perbedaan nyata. Respon kelompok PKK secara umum terhadap program pengabdian kepada masyarakat ini sangat baik karena program ini dinilai dapat memberikan manfaat secara nyata bagi kelompok PKK di wilayah setempat
\end{abstract}

Kata kunci: Penganekaragaman; Olahan Ternak; Kelompok PKK

ABSTRACT. Fulfillment of good food needs with sufficient quality is one of effort that must be taken to achieve the society safety in the globalization era. Unfortunately on the rural communities this is has not been achieved. Lack of knowledge and skills become one of the cause.The introduction of livestock-based products diversification is one of the right solutions. The potential of animals husbandry and human resources (PKK group) in Cibereum village expected could support to increasing incomes and needs for the availability of nutritious food, especially animal protein. The method used in this activity is counseling and approach both personally and to PKK group in Cibereum Village. The results of this service programs can increase the knowledge and processing technology of product diversification. Result of T-test before and after counceling show a significant result. The PKK group's overall response to the service program is very good because it is considered to provide significant benefits to PKK groups in the local area

Key words: Diversificatio; livestock-based product; PKK group

\section{PENDAHULUAN}

Pemenuhan bahan pangan berkualitas dengan kuantitas yang mencukupi merupakan salah satu upaya yang harus ditempuh untuk tercapainya kesejahteraan masyarakat dalam era globalisasi saat ini. Namun kenyataan di lapangan khususnya masyarakat di pedesaan belum sepenuhnya terpenuhi, mengingat kondisi perekonomian saat ini dan terbatasnya pengetahuan dan ketrampilan masyarakat.

Masyarakat pedesaan tidak dapat dilepaskan dengan kehadiran ternak, khususnya ternak unggas yaitu ayam dan bebek serta ternak lainnya seperti domba dan kambing, khususnya di desa Cibereum memiliki potensi besar ketersediannya ternak tersebut, karena desa tersebut memilki topografi pertanian sawah dan kebun yang luas. Hal ini dimungkinkan karena kesuburan tanahnya, kelembaban, suhu dan ketersediaan air yang berlimpah.

Potensi ternak yang dimiliki Desa Cibeurem diharapkan dapat menunjang pendapatan dan kebutuhan masyarakat akan tersedianya makanan bergizi, khususnya protein hewani. Kualitas dan kelengkapan asam amino yang ada dalam protein, menjadikan pangan hewani sangat dibutuhkan manusia dalam periode pertumbuhan dan untuk pembentukan dan penggantian jaringan yang rusak, namun tanpa penanganan yang baik bahan pangan hasil ternak mudah mengalami kerusakan.
Kerusakan bahan pangan hasil pertanian segera terjadi setelah panen, khususnya bahan pangan hasil ternak yang memiliki nilai nutrisi yang tinggi, sehingga bahan pangan ini tidak saja diperlukan bagi manusia juga merupakan media yang baik bagi tumbuh kembangnya mikroba. Oleh karena itu perlu dilakukan upaya pengawetan atau pengolahan agar bahan pangan ini dapat disimpan lebih lama, dan sekaligus merupakan upaya penganeka ragaman pangan hasil olahan ternak, diantaranya melalui transfer teknologi penyimpanan dan pengolahan.

Peningkatan daya beli masyarakat menyebabkan perlunya berbagai variasi pangan olahan hasil ternak. Beberapa jenis olahan daging yang kini banyak beredar dipasaran adalah bakso, nugget, sosis, abon, dendeng dan sebagainya, sedangkan produk olahan telur diantaranya telur asin, telur pindang dan telur berbagai rasa telur. Produk-produk olahan hasil ternak tersebut dapat dikerjakan dalam skala industri besar, menengah, maupun rumah tanggga. Sehingga peralatan sederhana yang dimiliki warga desa bukan merupakan suatu kendala. Namun demikian terbatasnya ilmu pengetahuan dan keterampilan ibu-ibu rumah tangga dalam mengolah produk hasil ternak masih merupakan kendala.

Berdasarkan uraian tersebut diatas, perlu dilakukan penyuluhan dan praktek cara pengawetan dan pengolahan dari ternak yang menjadi potensi di Desa Cibeurem, 
sehingga masyarakat tersebut dapat memperpanjang masa simpan dan mampu mengolahnya menjadi produk pangan hasil ternak untuk keperluan sendiri maupun untuk komersial, sehingga pada gilirannya dapat meningkatkan kesehatan dan kesejahtraan masyarakat setempat.

Tujuan dari program pengabdian kepada masyarakat ini adalah:

1. Tujuan dilakukan kegiatan pengabdian kepada masyarakat ini adalah untuk meningkatkan pengetahuan, keterampilan, dan kemampuan masyarakat (khususnya kelompok PKK) dalam mengolah bahan pangan sumber ternak menjadi makanan yang bergizi dan berdaya guna untuk meningkatkan pendapatan

2. Pembinaan dan pemberdayaan kelompok PKK dalam mengakses pengetahuan dan teknologi yang sesuai dengan kebutuhan dan sumber daya yang tersedia.

\section{METODE}

Adapun metode yang digunakan pada proses pembelajaraan yang dilaksanakan adalah sebagai berikut:

1. Melakukan Pretest kepada ibu-ibu rumah tangga/ PKK, masyarakat umum yang bersedia mengikuti pelatihan yang akan terlibat dalam penerapan pengabdian kepada mayarakat untuk melihat berapa besar tingkat pengetahuan mereka akan pengawetan dan penganekaragam produk telur.

2. Mengadakan pelatihan berupa teori-teori yang mudah dipahami kepada ibu-ibu rumah tangga/PKK, masyarakat umum yang akan terlibat dalam penerapan pengabdian kepada mayarakat.

3. Mengadakan praktek-paktek yang berhubungan dengan pengawetan dan penganekaragam produk telur yang mudah dan sehat kepada ibu-ibu rumah tangga/PKK, masyarakat umum yang akan terlibat dalam penerapan pengabdian kepada mayarakat.

4. Melakukan Post-test kepada ibu-ibu rumah tangga/ PKK, masyarakat umum yang terlibat dalam penerapan pengabdian kepada mayarakat untuk melihat berapa besar tingkat pengetahuan mereka akan pengawetan dan penganekaragam produk telur setelah diberikan pelatihan serta praktek secara mandiri didampingi instruktur-instruktur yang handal.

Evaluasi hasil, yaitu dengan cara membandingkan hasil sebelum dan sesudah dilakukannya PKM

\section{HASIL DAN PEMBAHASAN}

Peserta program pengabdian kepada masyarakat yang di ikuti sebanyak 42 orang yang terdiri dari 21 peserta asal Desa Cibereum dan 20 peserta dari mahasiswa KKNM, dan pelaksanaan kegiatan masing masing diikuti 27 peserta. Dari keseluruhan peserta tidak semuanya berasal dari kelopmpok PKK, namun dari berbagai bidang pekerjaan dan keahlian lainnya yang tertarik untuk hadir dalam acara penyuluhan ini yaitu petani, aparat desa, pengurus kelompok, masyarakat umum, dll.
Partisipan sangat antusias mengikuti acara penyampaian materi maupun praktik. Antusiasme ini diwujudkan dalam pernyataan yang disampaikan kepada pembawa materi dan rekan. Antusiasme partisipan ini karena pada Desa Cibereum ternyata belum pernah ada penyuluhan mengenai teknologi pengolahan produk peternakan (khususnya telur asin, telur pindang dan abon ayam). Hal ini ditunjukan saat proses diskusi yang sangat aktif, sementara yang lainnya tampak mencatat apa yang disampaikan. Penyampaian materi diselingi dengan pertanyaan dari peserta. Setelah dijawab, penyampaian materi dilanjutkan kembali. Selesai penyampaian materi, program pengabdian kepada masyarakat dilanjutkan dengan praktik pembuatan telur asin, telur pindang dan abon ayam yang dilaksanakan setiap minggu sebanyak 3 kali pertemuan. Saat praktik dan setelah selesai pun masih terjadi tanya jawab antara partisipan dan pelaksana program.

\section{Indikator Keberhasilan}

Hampir seluruh peserta belum pernah mengolah atau membuat telur asin, telur pindang dan abon ayam. Mulai dari bagaimana cara memilih bahan baku yang baik, cara menyimpan yang baik dan mengolah menjadi bahan yang siap untuk dikonsumsi. Dengan demikian, peserta harus diberi penjelasan dengan bahasa yang sederhana tentang. Pemberian materi dan praktik pengolahan pembuatan telur asin, telur pindang dan abon ayam memberi hasil berupa peningkatan pengetahuan kognitif, keterampilan, dan evaluasi pengetahuan teknologi pengolahan nugget dan telur asin dapat dilihat pada Tabel 4 berikut.

Tabel 1. Rangkuman Hasil Kegiatan Program Pengabdian Kepada Masyarakat Penganekaragaman Produk Ternak

\begin{tabular}{lll}
\hline \multirow{2}{*}{ Kinerja kegiatan } & \multicolumn{2}{c}{ Kondisi } \\
\cline { 2 - 3 } Langkah kegiatan & \multicolumn{1}{c}{ Sebelum } & \multicolumn{1}{c}{ Sesudah } \\
& dengan lurah: & Pemberian materi, \\
& penentuan, & dan evaluasi hasil \\
& pembuatan, & dari pembuatan telur \\
& dan penyebaran & asin, abon ayam dan \\
& undangan, & telur pindang. \\
& penyiapan tempat, & \\
& penyiapan acara & \\
& & \\
&
\end{tabular}

Indikator capaian

Pengetahuan kelompok

PKK terhadap produk olahan ternak

Pengetahuan kognitif

kelompok terhadap

produk olahan ternak

Mempraktekan pembuatan

nugget dan telur asin

Mengolah produk untuk

menambah penghasilan

Target

Pengetahuan kelompok Meningkat 25\% Meningkat 87,5\%

\begin{tabular}{ll}
$10 \%$ & $80 \%$ \\
$20 \%$ & $85 \%$ \\
\hline $15 \%$ & $75 \%$ \\
$15 \%$ & $70 \%$
\end{tabular}

olahan ternak 
Pengetahuan kognitif

kelompok terhadap

produk olahan ternak

Mempraktekan

pembuatan nugget dan

telur asin

Mengolah produk untuk

menambah penghasilan

\section{Faktor Pendorong dan Penghambat}

Faktor pendorong program terhadap kuliah kerja nyata mahasiswa program pengabdian kepada masyarakat dosen integratif berupa program yang belum pernah dilaksanakan sebelumnya di tempat tersebut, keinginan untuk mengetahui bagaimana cara mengolah telur asin, telur pindang dan abon ayam. Sedangkan, yang menjadi faktor penghambat adalah bahasa yang perlu disesuiakan dengan kodisi keseharian Ibu-Ibu PKK yang sering digunakan serta ketidaktahuan.

\section{Pembahasan}

Hasil evaluasi yang didapatkan saat pre test dan post test menunjukan hasil yang baik dengan $\mathrm{t}$ hit $>\mathrm{t}$ tabel $(3,52>2,045)$. Dari hasil perhitungan tersebut dapat dilihat adanya peningkatan prilaku dari peserta yang sebelumnya kurang memahami dan mengetahui pengolahan produk asal peternakan (pengolahan telur asin, telur pindang dan abon ayam) menjadi memahami dan mengetahui bagaimana cara mengolahan produk peternakan yanga baik dan sehat agar dapat menunjang kesehatan keluarga serta lebih lanjut dapat menningkatkan tingkat perekonomian keluarga dengan dapat membuka usaha rumah tangga dengan cara pengolahan produk peternakan.

Hal lain juga terlihat juga dari antusiasme ibuibu PKK pada saat pelaksanaan kuliah dan praktek pengolahan melalui pertanyaan-pertanyaan ibu-ibu PKK terhadap apa yang sedang dijelaskan. Ibu-ibu PKK juga mengharapkan adanya program berkesinambungan untuk memberikan penyuluhan mengenai hal-hal yang berkaitan dengan pengolahan produk-produk hasil ternak.

Pelaksanaan penyuluhan ini mendapatkan sambutan yang baik dari Pemerintahan setempat, Bapak Kades beserta stafnya memberikan respon yang sangat baik dari awal masa penjajagan dan pendekatan kepada masyarakat kemudian kerja sama yang baik pada saat pelaksanaan sampai akhir acara. Bapak Kades juga menghimbau kepada masyarakat desa juga diharapkan mendapatkan dan mencari pengetahuan sebanyak-banyaknya dari penyuluhan ini karena Bapak Kades akan menggangkarkan pinjaman ringan untuk UMKM bagi warga Desa Cibereum yang berkeinginan untuk memulai usaha.

\section{Perubahan yang Terjadi}

Penyuluhan tentang penganekaragaman olahan ternak berupa pengolahan telur asin, abon ayam dan telur pindang belum pernah dilaksanakan di Desa Cibereum. Pemberian materi, contoh hasil, dan uji coba sangat meningkatkan pengetahuan praktis mereka. Berdasarkan hasil diskusi dan evaluasi dengan kelompok PKK dari Desa Cibereum, tampaknya diperlukan program penyuluhan lebih lanjut dalam rangka memperkaya produk hasil ternak yang memungkinkan untuk diperkenalkan berikut cara pengolahannya.

Perubahan yang diharapkan terjadi dari hasil penyuluhan dimaksudkan untuk mengubah dalam arti agar kelompok Ibu-Ibu PKK dan keluarganya memiliki dan dapat meningkatkan perilakunya mengenai:

1. Sikap yang lebih progresif dan motivasi tindakan yang rasional

2. Pengetahuan luas dan mendalam terutama mengenai ilmu teknis pengolahan produk hasil ternak dan yang berkaitan.

Keterampilan teknis berusaha yang baik sehingga meningkatkan kemampuan mengelola usaha yang efektif secara teknis dan ekonomis sehingga dapat menambah penghasilan keluarga.

\section{SIMPULAN}

Dari hasil kegiatan pengabdian kepada masyarakat maka dapat disimpulkan: Penyuluhan nyata berpengaruh meningkatkan pengetahuan peserta dalam pengolahan daging ayam dan telur. Kelompok Ibu-Ibu PKK dapat menerima dengan baik olahan hasil ternak (telur asin, telur pidang dan abon ayam); Praktek pengolahan daging da ntelur berhasil memberikan pengalaman dan sekaligus keterampilan dalam pengolahan daging ayam dan telur.

\section{UCAPAN TERIMAKASIH}

Penulis mengucapkan terima kasih kepada Direktur Riset, Pengabdian pada Masyarakat dan Inovasi Universitas Padjadjaran yang telah mendanai progam pengabdian di Desa Cibereum Kecamatan Talaga, Kabupaten Majalengka. Tidak lupa juga penulis ucapkan terima kasih kepada Kepala Desa Cibereum yang telah membantu terselenggaranya acara pembelajaran ini.

\section{DAFTAR PUSTAKA}

Amertiningtyas, D., H.Purnomo dan Siswanto. 2001. Kualitas Nugget Daging Ayam Broiler dan Ayam Petelur Afkir Dengan Menggunakan Tepung Tapioka Modifikasi Serta Lama Pengukusan Yang Berbeda. Biosain Vol.1 No. 1.98-99, 101-102

Bambang Suharno. 2004. Data Bisnis Peternakan. Dirjen Peternakan. Departemen Pertanian Republik Indonesia.

Badan Perencanaan Pembangunan nasional dan Departemen Dalam Negeri. 1993. Panduan Inpres Desa Tertinggal. Jakarta. Hal. 7-9, 27, 41. 
Direktorat Jenderal Peternakan. 1993. Ketentuan Usaha Peternakan II. Direktorat Jenderal Peternakan Departemen Pertanian. Jakarta. Hal. 6.

Google. 2015. Google Map. Diunduh 20 Oktober 2016 jam 11.00.

Huky, W.D.A. 1988. Mentalitas Manusia Indonesia. Beria Harian Kompas, 24 Oktober. Jakarta.

Henrickson, R.L. 1978. Meat, Poultry and Seafood Technology. Prentice Hall Inc. Englewood Cliffs, New Jersey

Indrawijaya, A.I. 1986. Perilaku Organisasi. Cetakan ketiga. Sinar Baru. Bandung. Hal. 90-91.

Kartono, K. 1983. Psikologi Sosial: Perusahaan dan Industri. Cv Rajawali. Jakarta. Hal. 48.

Lawrie, R.A. 1985. Meat Science. Edisi Ketiga. Penerbit Ed Pergamon Press, New York

Maunder, A.H. 1972. Agricultural Extension, A Reference Manual. Food and Agriculture Organization. Rome. Pp. 70-71.

McLelland, D.C. 1961. The Achieving Society. The Free Press. New york. Pp. 36-62.

Mosher, A.T. 1968. Getting Agriculture Moving. Cetakan ketiga. Diterjemahkan oleh Krisandhi, S. dan B. Samad. Cv Yasaguna. Jakarta. Hal. 97, 133-149, 163-172, 183-186.
Obin Rachmawan. 2001. Hubungan Antara Waktu dan Suhu Penggorengan Abon Daging Ayam. Fakultas Peternakan Unpad

Standar Nasional Indonesia. 1995. No.01-3820-1995. Tentang Sosis.

Soekanto, S. 1996. Sosiologi Suatu Pengantar. Edisi kedua. Cetakan ketujuh. Cv rajawali. Jakarta. Hal. 103-105.

Soeparno. 1998. Ilmu dan Teknologi Daging. Gadjah Mada University Press. Yogyakarta. Hal 249-251

Sugarda, T.J. dan R.S. Iskandar. 1979. Dasar-dasar Penyuluhan Pertanian. Fakultas Pertanian, Universitas Padjadjaran. Bandung. Hal. 36.

Tullis, L.M. 1970. World Agricultural Structure. FAO Review. FAO-UN Organization. Rome. P. 212.

Wibowo, S. 2001. Pembuatan Bakso Ikan dan Bakso Daging. Penebar Swadaya. Jakarta.

Winarno, F.G.1997. Kimia Pangan dan Gizi. PT.Gramedia. Hal 27-33.

Wiriaatmadja. 1982. Pokok-pokok Sosiologi Pedesaan. Cetakan kedelapan. Cv Yasaguna. Jakarta. Hal. $7-8$. 